\title{
Unexpected Circumstances arising from World War I and its Aftermath: 'open' versus 'closed' legal systems
}

Citation for published version (APA):

Oosterhuis, J. (2014). Unexpected Circumstances arising from World War I and its Aftermath: 'open' versus 'closed' legal systems. Erasmus Law Review, 7(2), 67-79. https://doi.org/10.2139/ssrn.2508347

Document status and date:

Published: 01/01/2014

DOI:

$10.2139 /$ ssrn.2508347

Document Version:

Publisher's PDF, also known as Version of record

\section{Document license:}

Unspecified

\section{Please check the document version of this publication:}

- A submitted manuscript is the version of the article upon submission and before peer-review. There can be important differences between the submitted version and the official published version of record.

People interested in the research are advised to contact the author for the final version of the publication, or visit the DOI to the publisher's website.

- The final author version and the galley proof are versions of the publication after peer review.

- The final published version features the final layout of the paper including the volume, issue and page numbers.

Link to publication

\footnotetext{
General rights rights.

- You may freely distribute the URL identifying the publication in the public portal. please follow below link for the End User Agreement:

www.umlib.nl/taverne-license

Take down policy

If you believe that this document breaches copyright please contact us at:

repository@maastrichtuniversity.nl

providing details and we will investigate your claim.
}

Copyright and moral rights for the publications made accessible in the public portal are retained by the authors and/or other copyright owners and it is a condition of accessing publications that users recognise and abide by the legal requirements associated with these

- Users may download and print one copy of any publication from the public portal for the purpose of private study or research.

- You may not further distribute the material or use it for any profit-making activity or commercial gain

If the publication is distributed under the terms of Article $25 \mathrm{fa}$ of the Dutch Copyright Act, indicated by the "Taverne" license above, 


\title{
Unexpected Circumstances arising from World War I and its Aftermath: 'Open' versus 'Closed' Legal Systems
}

\author{
Janwillem Oosterhuis*
}

\begin{abstract}
European jurisdictions can be distinguished in 'open' and 'closed' legal systems in respect of their approach to unexpected circumstances occurring in contractual relations. In this article, it will be argued that this distinction can be related to the judiciary's reaction in certain countries to the economic consequences of World War I. The first point to be highlighted will be the rather strict approach to unexpected circumstances in contract law that many jurisdictions had before the war - including England, France, Germany, and the Netherlands. Secondly, the judicial approach in England, France, Germany, and the Netherlands to unexpected circumstances arising from the war will be briefly analysed. It will appear that all of the aforementioned jurisdictions remained 'closed'. Subsequently, the reaction of the judiciary in these jurisdictions to the economic circumstances in the aftermath of the war, (hyper)inflation in particular, will be analysed. Germany, which experienced hyperinflation in the immediate aftermath of the war, developed an 'open' system, using the doctrine of the Wegfall der Geschäftsgrundlage. In the Netherlands, this experience failed to have an impact: indeed, in judicial practice the Netherlands appears to have a 'closed' legal system nevertheless, save for an 'exceptional' remedy in the new Dutch Civil Code, Article 6:258 of the Burgerlijk Wetboek (1992). In conclusion, the hypothesis is put forward that generally only in jurisdictions that have experienced exceptional economic upheaval, such as the hyperinflation in the wake of World War I, 'exceptional' remedies addressing unexpected circumstances can have a lasting effect on the legal system.
\end{abstract}

Keywords: First World War, law of obligations, unforeseen circumstances, force majeure, frustration of contracts

\section{Introduction}

European jurisdictions can be distinguished in 'open' and 'closed' legal systems in respect of their approach to unexpected circumstances occurring in contractual relations. In this distinction, 'open' legal systems have

Janwillem Oosterhuis is Assistant Professor in Methods and Foundations of Law at the Maastricht University Faculty of Law. For the language check, I would like to thank Lawrence Reddy. established a general 'exceptional' doctrine specifically addressing the issue of unexpected circumstances that can lead to an adjustment of the contract. 'Closed' legal systems do not offer such a solution either because they do not have such an 'exceptional' doctrine or, even if they have such a doctrine (as most jurisdictions do), this doctrine generally cannot lead to an adjustment of the contract. ${ }^{1}$

In this article, it will be argued that this distinction can be related to the judiciary's reaction in certain countries to the economic consequences of World War I. The first point to be highlighted will be the rather strict approach to unexpected circumstances in relation to contractual obligations that many jurisdictions had before the war - including England, France, Germany, and the Netherlands. Basically all European jurisdictions were 'closed' before the First World War: unsurprising, taking into account the overall favourable and stable economic conditions since around the 1850s.

Secondly, the judicial approach in England, France, Germany, and the Netherlands to unexpected circumstances arising from the war will be briefly analysed. It will appear that all of the aforementioned jurisdictions remained 'closed'.

Subsequently, the reaction of the judiciary in these jurisdictions to the economic circumstances in the aftermath of the war, (hyper)inflation in particular, will be analysed. Germany, which experienced hyperinflation in the immediate aftermath of the war, developed an 'open' system, using the doctrine of the Wegfall der Geschäftsgrundlage. The experience gained from this event was used in other European countries when they had to deal with the consequences of great economic and political instability, not only in the aftermath of World War I but also of inter alia World War II. In the Netherlands, this experience failed to have an impact: indeed, in judicial practice the Netherlands appears to have a 'closed' legal system nevertheless, save for an 'exceptional' remedy in the new Dutch Civil Code, Article 6:258 of the Burgerlijk Wetboek (1992).

In conclusion, the hypothesis is put forward that generally only in jurisdictions that have experienced exceptional economic upheaval, such as the hyperinflation in

1. See E. Hondius and H.C. Grigoleit, 'Introduction: An approach to the issues and doctrines relating to unexpected circumstances', in E. Hondius and H.C. Grigoleit (eds.), Unexpected Circumstances in European Contract Law (2011) 3, at 10-11. 
the wake of World War I, 'exceptional' remedies addressing unexpected circumstances can have a lasting effect on the legal system.

\section{Pre-1914: the Reign of Absolute Impossibility}

Since the 1870s, Europe, and particularly Western Europe including Britain, the German Empire, France, and the Netherlands, witnessed a period of considerable economic growth. This growth was the result of, amongst others, technological progress and the liberalisation of trade. ${ }^{2}$ Between 1871 and 1914, industrial production in France and Britain more than doubled, whereas the German industrial production rose more than fivefold. ${ }^{3}$ In that same period, French external trade - import and export - did not even double, British trade roughly doubled, German trade rose threefold, and Dutch trade even fivefold. ${ }^{4}$ Prices were nevertheless stable and inflation low; this was also due to the adherence to the Gold Standard. ${ }^{5}$

This economic growth and the increase in trade required a timely performance of commercial transactions: protection of the debtor - here in the broad sense of a party to whom an obligation is owed - was of secondary importance. ${ }^{6}$ Against this background, the rather strict approach of legislatures and judiciaries towards unexpected circumstances seems understandable enough. Moreover, the Modern Natural Law of the sev-

2. See in general E. Damsgaard Hansen, European Economic History (2001), at 155-173; F.B. Tipton and R. Aldrich, An Economic and Social History of Europe, 1890-1939 (1987), at 9-26; T. Pierenkemper and R. Tilly, The German Economy during the Nineteenth Century (2004), at 143-51. See also W.O. Henderson, The Rise of German Industrial Power 1834-1914 (1975), at 186-98.

3. See B.R. Mitchell, European Historical Statistics 1750-1970 (1978), at 179-81 (Table D1, Indices of Industrial Production; in this table no data are available for the Netherlands for this period). See also H.J. Braun, The German Economy in the Twentieth Century (1990), at 19-23.

4. See Mitchell, Statistics (1978), at 297-307 (Table E1, External Trade). See also W. Ashworth, An Economic History of England 1870-1939 (1960), at 138-62.

5. See Mitchell, Statistics (1978), at 356-60 (Table G1, Banknote Circulation), 389-91 (Table H1, Wholesale Price Indices). See also Tipton, Europe (1987), at 43-6.

6. E.M. Meijers, 'Behoort verandering in de feitelijke omstandigheden, waaronder een overeenkomst is gesloten, invloed te hebben op haar voortbestaan? Zoo ja, welke wettelijke regeling is te dien aanzien wenschelijk?', in Handelingen der Nederlandsche Juristen-Vereeniging I.1 (1918) 85, at 124. In detail J. Oosterhuis, Specific Performance in German, French and Dutch law in the Nineteenth Century (2011), at 237-394. enteenth and eighteenth centuries provided a theoretical foundation for this uncompromising approach. ${ }^{7}$

\subsection{England}

Since at least the seventeenth century, the English legal system was rather uncompromising in respect to contractual duties. ${ }^{8}$ The general rule was that a change of circumstances after a promise was made did not excuse the promisor from performance, even if it made performance impossible, see the rule in Paradine v. Fane. ${ }^{9}$ In 1863, however, in Taylor v. Caldmell, ${ }^{10}$ the parties were discharged of their contractual duties because a particular, specified thing that was needed to perform the contract had perished - here the Surrey Music Hall. This discharge upon the perishing of the thing without the party's fault was considered an implied condition. ${ }^{11}$ Frustration of contract became also accepted in cases of maritime ventures, where the notion was embraced that a contract might be terminated if its commercial purpose was frustrated (see the rule in Fackson v. Union Marine Insurance Company in 1874). ${ }^{12}$ The doctrine of frustration was subsequently extended to cases where performance was strictly speaking still possible, but the commercial purpose of the contract was frustrated, such as in one of the coronation cases, Krell v. Henry. ${ }^{13}$ But

7. For the historical development of the clausula rebus sic stantibus doctrine, and its decline in the eighteenth and nineteenth centuries, see e.g. R. Zimmermann, “'Heard Melodies are sweet, but those unheard are sweeter" - Condicio tacita, implied condition und die Fortbildung des europäischen Vertragsrecht', 193 Archiv für die Civilistische Praxis 123 , at 135-36 (1993); A. Thier, 'Legal History', in E. Hondius and H.C. Grigoleit (eds.), Unexpected Circumstances in European Contract Law (2011) 15, at 25-30; R. Meyer-Pritzl, ‘§\$313-314: Störung der Geschäftsgrundlage. Kündigung von Dauerschuldverhältnisse aus wichtigen Grund', in M. Schmoeckel, J. Rückert \& R. Zimmermann (eds.), Historisch-Kritischer Kommentar zum BGB (2008), at II.4-5.

8. See G.H. Treitel, The Law of Contract (2003), at 866-67; G.H. Treitel, Frustration and Force Majeure (1994), at 13-61; Zimmermann, Heard Melodies (1993), at 137-42; H. Rösler, 'Hardship in German Codified Private Law - in Comparative Perspective to English, French and International Contract Law', European Review of Private Law 483, at 497-98 (3-2007)

9. Paradine v. Jane (1647) Aleyn 26. See A.W.B. Simpson, 'Innovation in Nineteenth Century Contract Law', in A.W.B. Simpson, Legal Theory and Legal History (1987) 171, at 194; C. MacMillan, 'Taylor v Caldwell (1863)', in Ch. Mitchell and P. Mitchell (eds.), Landmark Cases in the Law of Contract (2008) 167, at 181-82; M. Lobban, 'Contract', in W.R. Cornish et al. (eds.), The Oxford History of the Laws of England, Volume XII 1820-1914 (2010) 295, at 509.

10. Taylor v. Caldwell (1863) 3 B. \& S. 826. On this case see MacMillan, Taylor v Caldwell (2008), at 167. See also A.D. McNair and A.D. Watts, The Legal Effects of War (1966), at 159-60; Lobban, Contract (2010), at 513-14; Treitel, Contract (2003), at 867; H. Beale et al. (eds.), Cases, Materials and Text on Contract Law (2010), at 1110; Meijers, Verandering (1918), at 99.

11. On the continental influences on this doctrine, via Pothier and Blackburn J., see Simpson, Innovation (1987), at 194-95; MacMillan, Taylor v Caldwell (2008), at 193-94; Lobban, Contract (2010), at 514.

12. Jackson v. Union Marine Insurance Company (1874) L.R. 10 C.P. 125. See McNair, War (1966), at 163-65; Lobban, Contract (2010), at 516-17.

13. Krell v. Henry (1903) 2 K.B. 740. See McNair, War (1966), at 161-62; Lobban, Contract (2010), at 518-19; Trotter, Contract (1940), at 122-23; Treitel, Contract (2003), at 866-67; Beale, Contract (2010), at 1114; Meijers, Verandering (1918), at 101. See, for an overview of more nineteenth century cases, MacMillan, Taylor v Caldwell (2008), at 199-201; Lobban, Contract (2010), at 508-17; Zimmermann, Heard Melodies (1994), at 140-42. 
here too the remedy was still rescission of contract. ${ }^{14}$ Moreover, extreme and unforeseen cost or difficulty of performance itself, i.e. 'commercial impossibility', was not held to be an excuse for non-performance. ${ }^{15}$

\subsection{France}

In French private law, the effect of changed or unforeseen circumstances upon existing contractual relations had traditionally been handled through the doctrine of force majeure (Articles 1147 and 1148 of the Code civil). Unless a party had assumed the risk of impossibility, no liability was incurred for non-performance if it was impossible to perform the contract due to an event that the parties could not reasonably have been expected to foresee at the conclusion of the contract. ${ }^{16}$ Even temporal but indefinite impossibility could result in dispensation of the party unable to perform. ${ }^{17}$

However, if performance was still possible, the Cour de Cassation refused to give relief on the grounds of change of circumstances, which is demonstrated in the Canal de Craponne case of 1876. Here, the Cour de Cassation decided that the Cour d'appel d'Aix-en-Provence had violated Article 1134 of the Code civil in adapting a contract concerning the maintenance costs of the Craponne canal. Although the contract was from 1567, long before the promulgation of the Code civil in 1804, the Cour de Cassation considered the adagium pacta sunt servanda, contained in Article 1134, to be general and absolute. ${ }^{18}$ The principle of good faith, laid down in the same Article 1134 , was virtually never applied to adjust contracts. ${ }^{19}$

\subsection{German Empire}

The Bürgerliches Gesetzbuch, reflecting a liberal economic theory resting on individual autonomy and freedom of ownership then prevailing, did not accord effects to changed or unforeseen circumstances unless they rendered performance of the contract impossible in a strict

14. Treitel, Contract (2003), at 867; Treitel, Frustration (1994), at 48.

15. E.g. Hong-Kong and Whampoa Dock Co.Ltd. v. Netherton Shipping Co.Ltd. (1909) S.C. 34; Brown v. Royal Insurance Co. (1859) 1 E. \& E. 853. See Trotter, Contract (1940), at 115.

16. A.T. von Mehren and J.R. Gordley, The Civil Law System (1977), at 1049. See also J. Ghestin, C. Jamin \& M. Billiau, Traité de Droit Civil: Les effets du contrat (2001), at 326; M. Fabre-Magan, Droit de obligations, 1 - Contrat et engagement unilatéral (2010), at 643; H., L., and J. Mazeaud and F. Chabas, Leçons de droit civil, II-1: Obligations-théorie générale (1998), at 573-80; Beale, Contract (2010), at 1095; Rösler, Hardship (2007), at 500-501; F.E. Cooper, 'Effects of Inflation on Private Contracts: France, 1916-1926', 6 Detroit L. Rev. 63, at 69-70 (1936).

17. E.g. Cass., 7 May 1872, D. 72.1.456; Cass. 23 February 1872, D. 72.1.187. See Meijers, Verandering (1918), at 97.

18. Cass. Civ., 6 March 1876, De Galliffet v. Commune de Pélissane, D. 1876.1.193. See Mazeaud, Leçons (1998), at 736; Ghestin, Effets (2001), at nos. 296, 307; Fabre-Magan, Contrat (2010), at 480; Beale, Contract (2010), at 1030-32; Von Mehren, Civil Law (1977), at 1050-51; Rösler, Hardship (2007), at 500-501. See also Cass. Civ., 9 January 1856, D.P. 1856.1.33; Cass. Civ., 24 March 1874, Comuset, Heina et comp. v. Way, S. 1874.1.428

19. See E.M. Meijers, 'Goede trouw en stilzwijgende wilsverklaring', in Mededeelingen der Koninklijke Nederlandsche Akademie van Wetenschappen, Afd. Letterkunde, Deel 84, Serie B, no. 5 (1937), reissued in E.M. Meijers, Verzamelde privaatrechtelijke opstellen. Derde deel - Verbintenissenrecht (1955), at 279-80. and objective sense. ${ }^{20}$ The drafters intended that the provisions concerning impossibility of performance - inter alia $\$ \$ 275(1), 280,282$, and 287 - were to be narrowly construed and restricted to cases in which performance could be deemed literally 'impossible' rather than merely 'extremely onerous'.21 They moreover explicitly rejected inclusion of a general clausula rebus sic stantibus doctrine. ${ }^{22}$ Finally, no one considered the good faith provision of the Bürgerliches Gesetzbuch $\S 242$ to be relevant for dealing with the problem of changed or unforeseen circumstances. ${ }^{23}$

Nevertheless, even before the war, courts sometimes assimilated a debtor's subsequent 'inability' to perform with objective, subsequent impossibility (a notion found in the Code) and extended it to economic impossibility. ${ }^{24}$ In 1889 , the Reichsgericht had already held that even a temporal inability to perform could lead to rescission of a contract: here a buyer claimed delivery after a period of eight months, in which the supplier had rebuilt his mill that had burned down. ${ }^{25}$ Furthermore, in B. v. Bremer Rolandmühle of 1904, the seller was relieved of his duty to deliver a specific cottonseed product (Eichenlaub) because it had become so exceptionally difficult that it was considered by commerce as the equivalent to impossible - here the seller was the sole producer of this product and his specialist mill had burned down. The seller's duty to attempt finding supplies of his own product was not without limit: he could not be required to attempt to buy his brand on all German and foreign markets. ${ }^{26}$

\subsection{The Netherlands}

The Dutch Civil code of 1838, the Burgerlijk Wetboek, was largely a copy of the French Code civil, which had been in force until then. Therefore, as in French private law, the effect of changed or unforeseen circumstances upon existing contractual relations had traditionally been handled through the doctrine of force majeure (Articles 1280 and 1281 of the Burgerlijk Wetboek). Unless a party had assumed the risk of impossibility, no liability was incurred for non-performance if it was

20. See F. Wieacker, 'Das Sozialmodell der klassischen Privatrechtsgesetzbücher und die Entwicklung der modernen Gesellschaft (1953)', in F. Wieacker, Industriegesellschaft und Privatrechtsordnung (1974) 9, at 14; H. Dörner, 'Erster Weltkrieg und Privatrecht', 17 Rechtstheorie 385, at 385 (1986); J.P. Dawson, 'Effects of Inflation on Private Contracts: Germany, 1914-1924', 33 Mich. L. Rev. 171, at 175-7 (1934). See also Von Mehren, Civil Law (1977), at 1066.

21. See 2 Motive zu dem Entwurfe eines bürgerlichen Gesetzbuches (1888), at 44-46. See for an overview of some pre-war cases, Oosterhuis, Specific Performance (2011), at 303-6.

22. See 2 Motive (1888), at 199. See also Wieacker, Sozialmodell (1974), at 15.

23. Von Mehren, Civil Law (1977), at 1066.

24. E.g. Reichsgericht, 3 February 1914, 84 ERGZ 125. See Beale, Contract (2010), at 1105-6.

25. Reichsgericht, 12 July 1889, SeuffA 45, 176. See on this decision Meijers, Verandering (1918), at 95. See also e.g. Reichsgericht, 6 July 1898, 45 ERGZ 114.

26. Reichsgericht, 23 February 1904, 57 ERGZ 116. See on this decision Von Mehren, Civil Law (1977), at 1067-1068; B.S. Markesinis, H. Unberath \& A. Johnston, The German Law of Contract (2006), at 326-27. 
impossible to perform the contract due to an event that the parties could not reasonably have been expected to foresee at the conclusion of the contract, and which event could not be imputed to the non-performing party. ${ }^{27}$

Several courts, however, did not require an absolute or objective impossibility of the performance but held that force majeure existed if (i) it was for the debtor - temporarily - impossible to perform and (ii) he had made all efforts that could be reasonably required from him as a good housefather to perform. ${ }^{28}$ The scope of this subjective impossibility was even extended because often the creditor had to prove that his debtor's efforts should be considered insufficient. ${ }^{29}$ However, the event that prevented the debtor to perform had to be unforeseeable: the vagueness of this term gave courts considerable discretion to, in spite of this, keep a debtor responsible for his non-performance. ${ }^{30}$

An increase in prices was generally not accepted as force majeure. ${ }^{31}$ Just like the Cour de Cassation, the Hoge Raad virtually never revised contracts on the basis of the principle of good faith ${ }^{32}$ as laid down in, e.g. Article 1374 of the Burgerlijk Wetboek.

\section{1914-1918: Absolute Impossibility continued (but with Exceptions)}

In 1914, Europe and the rest of the world ended up in a war. The German government anticipated a short war to be won by military, not economic means. However,

27. See A.C. van Empel, Overmacht (1981), at 1-3.

28. E.g. Rb. Rotterdam, 18 June 1892, W. 6222 (temporal impossibility constitutes force majeure); Rb. Rotterdam, 15 March 1909, W. 8957; Rb. Amsterdam, 12 May 1911, W. 9281, confirmed Hof Amsterdam, 10 January 1913, W. 9534. Houwing had launched this definition of force majeure in 1904, J.F. Houwing, 'Overmacht of onmogelijkheid', R.M., at 250 (1904); but see already Hof Noord-Brabant, 6 April 1875, W. 3879 (in which case the facts and decision were similar to Reichsgericht, 23 February 1904, 57 ERGZ 116). See Meijers, Verandering (1918), at 133-35; S. van Brakel, Leerboek van het Nederlandsche Verbintenissenrecht I (1942), at 119-20; Oosterhuis, Specific Performance (2011), at 376-77. Critical M.G. Levenbach, De spanning van de kontraktsband (1923), at 61-62; J.L.L. Wery, Overmacht bij overeenkomsten (1919), at 114

29. E.g. HR, 26 April 1907, W. 8533. See Brakel, Leerboek (1942), at 122. Critical Levenbach, Kontraktsband (1919), at 106-31; Wery, Overmacht (1923), at 94-99.

30. E.g. Rb. Groningen, 9 July 1886, W. 5372 (no force majeure); Rb. Rotterdam, 29 June 1892, W. 6230 (no force majeure). See, for an overview of 14 pre-war cases in which courts generally held that the event creating the impossibility could have been foreseen, Wery, Overmacht (1919), at 94-95. See also Meijers, Verandering (1919), at 135; Brakel, Leerboek (1942), at 122; Oosterhuis, Specific Performance (2011), at 371.

31. Rb. Den Haag, 7 March 1912, W. v. N. en P. 2212. Otherwise Hof Den Haag, 3 February 1911, W. 9241. See Meijers, Verandering (1918), at 176.

32. HR, 24 April 1891, W. 6030 and HR, 8 April 1910, W. 9019 mentioned by Meijers, Goede trouw (1937), at 281, are less relevant, as these cases concern a revision based on a contractual clause, and not by the court on the basis of Article 1374(3) BW. particularly in the West, the war developed into one of attrition where the opposing forces of Germany, France, and Britain mobilised their entire economies. ${ }^{33}$ As a result, these and other European economies had to respond to different challenges which moreover changed over the course of the war.

In Britain, in August 1914, there was little appreciation of the sheer scale of the war effort that would be needed to defeat the Central Powers. Until 1917, state intervention in and management of the economy was relatively ad hoc in approach and tended to be reactive rather than proactive. As the war lengthened, the private-sectororiented 'business as usual' philosophy gave way to direct government control, and particularly the Ministry of Munitions expanded its role to cover a wide range of economic activities. The fact that real GDP increased during the war was also due to a dramatic increase in government expenditure. Britain was highly dependent on imported food supplies, as a result of the pre-war policy of free trade. These food imports were vulnerable to U-boat attack and mounting shipping losses brought about a change of policy, viz. to increase the production of grains and potatoes at the cost of the production of meat. During the war, the value of British imports almost doubled, although British exports stayed roughly the same. ${ }^{34}$ The annual average wholesale prices in Britain would not increase by any more than 100\% during the war, compared to the annual wholesale prices in $1914 .^{35}$

To the French economy, the war represented an enormous shock: at the end of the war, the French GDP had fallen to a trough more than $30 \%$ below its 1913 level. The break-up of trade relationships with Germany, Austria, Hungary, and soon Belgium and other invaded regions, representing around one-third of French imports and exports in 1913, seriously affected the goods markets. In real terms, French exports declined, reaching a low of one-third of their 1913 level in 1918. Imports, however, increased sharply from 1915 to 1917 , which also helped to compensate for the occupation of north-eastern France, and the decrease in French production of various goods. ${ }^{36}$ Direct state intervention remained limited: only in foreign trade did the state intervene more directly, but this came only in 1917. Although inflation started to rise, the annual average wholesale prices in France would not increase by any

33. See S. Broadberry and M. Harrison, 'The economics of World War I: an overview', in S. Broadberry and M. Harrison (eds.) The Economics of World War I (2005) 3, at 4; Tipton, Europe (1987), at 135-62.

34. S. Broadberry and P. Howlett, 'The United Kingdom during World War I: business as usual?', in S. Broadberry and M. Harrison (eds.) The Economics of World War I (2005) 206, at 206-13, 220-22. See also Mitchell, Statistics (1978), at 304-7 (Table E1, External Trade).

35. See Mitchell, Statistics (1978), at 389-91 (Table H1, Wholesale Price Indices); Broadberry, The United Kingdom (2005), at 218-19.

36. P.-C. Hautcoeur, 'Was the Great War a watershed? The economics of World War I in France', in S. Broadberry and M. Harrison (eds.) The Economics of World War I (2005) 169, at 170, 181-82. See also Mitchell, Statistics (1978), at 304-7 (Table E1, External Trade). 
more than $150 \%$ during the war, compared to the annual wholesale prices in $1914 .{ }^{37}$

German annual national income and output declined during the war. From 1916 onwards, when government control over the economy was tightened, the output of armament-related industries increased. However, output in other industries and agriculture decreased or dried up. The Allied naval blockade inflicted far greater damage on the German war economy than the German U-boat campaign did to England. In real terms, German imports during the war remained at $40-60 \%$ below their peacetime levels, while exports fell even further. ${ }^{38} \mathrm{Up}$ until 1916, Germany had been moderately successful in evading the Allied blockade by increasing imports of foodstuffs from the neighbouring neutrals, notably from the Netherlands and Denmark. But the intensified blockade after 1916 resulted in a sharp reduction of German food imports. ${ }^{39}$ Although inflation started to rise, the annual average wholesale prices in the German Empire would not increase by any more than 100\% during the war, compared to the annual wholesale prices in $1914 .^{40}$

Generally, the British, French, and German governments overestimated the importance of international trade in economic development and hence in a nation's capacity to wage war; all underestimated the resilience and flexibility of their domestic economies. In contrast to expectations, these nations proved able to reorganise their domestic economies in isolation from the international economy. ${ }^{41}$

The Dutch preserved neutrality, for instance through the Netherlands Overseas Trust Company, but had to accept many compromise measures against its sovereign rights. Trade and exports continued, with declining volumes but rising prices. Exports into Germany increased considerably and Dutch agricultural products helped Germany to continue its war effort. From 1913 to 1916, real GDP declined slightly to $96 \%$ of what it had been in 1913. Only the years 1917 and 1918 stand out as years of low economic activity due to trade limitations. ${ }^{42}$ Though inflation started to rise, the annual average wholesale prices in the Netherlands would not increase by any more than $150 \%$, compared to the annual wholesale prices in 1914 - probably also as a result of extensive government intervention in the economy, such as

37. Hautcoeur, France (2005), at 186-87, 193; Mitchell, Statistics (1978), at 389-91 (Table H1, Wholesale Price Indices).

38. A. Ritschl, 'The pity of peace: Germany's economy at war, 1914-1918 and beyond', in S. Broadberry and M. Harrison (eds.) The Economics of World War I (2005) 41, at 45-49, 51-52. See also Mitchell, Statistics (1978), at 304-7 (Table E1, External Trade).

39. Ritschl, Germany's Economy (2005), at 58-59.

40. See Mitchell, Statistics (1978), at 389-91 (Table H1, Wholesale Price Indices).

41. Tipton, Europe (1987), at 156.

42. H. de Jong, 'Between the devil and the deep blue sea: the Dutch economy during World War I', in S. Broadberry and M. Harrison (eds.) The Economics of World War I (2005) 137, at 139-44, 147, 164. See also Mitchell, Statistics (1978), at 304-7 (Table E1, External Trade). setting maximum prices and implementing export restrictions for basic foodstuffs. ${ }^{43}$

The war conditions resulted in hardship for contractual parties who (i) could not, or only against great cost obtain the goods they should deliver, or who (ii) could still deliver but saw their monetary counter performance greatly reduced in value. During the war itself, however, the English, French, German, and Dutch judiciary stuck largely to the existing approaches to dealing with cases where parties, due to the war, could no longer - or became highly unwilling to - perform their commercial sale contracts. In none of the jurisdictions would the courts revise a contract for unforeseen circumstances - except in France, where the Conseil d'état relied on the doctrine of imprévision: rescission thus remained the standard remedy in case of impossibility. The English and German courts, however, would sometimes discharge a contract if the performance - after a temporal impossibility - would amount to something else than originally contracted for. Discharge of a contract due to an increase in prices was basically not admitted anywhere. Admittedly, this pan-European judicial reluctance to interfere in private contractual relations can be related to the still prevailing liberal, individualist economic theories and the initial desire to continue with 'business as usual' - also because the war was expected to be shortlived. This deep reluctance against judicial interference in private contractual relations is reflected in the earlier decline of the clausula rebus sic stantibus doctrine in the eighteenth and nineteenth centuries and a simultaneous strong emphasis on the sanctity of contracts, the bindingness of contractual obligations, and the right to specific performance in this period. ${ }^{44}$

\subsection{England}

The First World War gave rise to a significant number of cases in which contracts were held to have been discharged by supervening impossibility. ${ }^{45}$ Even when performance was still possible, but a supervening event prevented a party to put the subject-matter, a person or thing, to the intended use, courts occasionally held contracts to be frustrated - in line with the rule in Krell v. Henry $^{46}$ (see, e.g., Horlock v. Beal). ${ }^{47}$

However, at the beginning of the war, courts appeared to be rather reluctant to discharge a contract, probably

43. See Mitchell, Statistics (1978), at 389-91 (Table H1, Wholesale Price Indices); De Jong, Dutch Economy (2005), at 157

44. See Zimmermann, Heard Melodies (1993), at 135-36; Thier, Legal History (2011), at 25-30; Oosterhuis, Specific Performance (2011), at 52-85, 90-6, 115-18, 127-29, 216-19, 221-32.

45. Treitel, Frustration (1994), at 49-50.

46. Krell v. Henry (1903) 2 K.B. 740

47. Horlock v. Beal (1916) A.C. 486 (a wife's claim for her husband's (a seaman) wages resulted in the discharge of the contract, due to the frustration of the adventure - or failure of consideration: see, critical, R.G. McElroy and G.L. Williams, Impossibility of Performance: A Treatise on the Law of Supervening Impossibility of Performance of Contract, Failure of Consideration, and Frustration (1941), at 152-55). Also e.g. Scottish Navigation Co. Ltd. v. W.A. Souter \& Co. (1917) 1 K.B. 222. See W.F. Trotter, The Law of Contract During and After War (1940), at 123-24; R. Gottschalk, Impossibility of Performance in Contract (1945), at 29-30; Treitel, Frustration (1994), at 292; Meijers, Verandering (1918), at 101 
also motivated by the initial desire to continue with 'business as usual'. If, for instance, not the entire purpose was frustrated, courts would not discharge a contract. Therefore, in 1916, a contract to 'provide, maintain, and light' street lamps was not frustrated when wartime black-out regulations prohibited the lighting of such lamps, since the maintenance obligation remained possible. $^{48}$ Also, if performance for some balance of a contract remained or was likely to remain possible, the outcome of claims for that balance depended on the proportion of the interruption or likely interruption to the contract period. For instance, long-term commission agency was held not to be frustrated when the agent was interned, since his internment was not likely to last long (and in fact only lasted one month) $;{ }^{49}$ the wartime requisition of a ship in February 1915 did not frustrate a fiveyear charter which was not due to expire till December 1917. ${ }^{50}$ In the latter case, Tamplin SS Co. Ltd. v. AngloMexican Petroleum Co., even though the contract was not discharged, Lord Loreburn stated that '... no Court has an absolving power, but it can infer from the nature of the contract and the surrounding circumstances that a condition which is not expressed was a foundation on which the parties contracted. ${ }^{\prime 51}$ This definition, by emphasising that discharge of a contract could also be based on an implied condition, helped to considerably widen the potential scope of impossibility of performance. $^{52}$

Towards the end of the war, indeed in extension of the rule in Taylor v. Caldmell, ${ }^{53}$ in several cases discharge was given because the subject-matter, a person or thing, had become - temporarily - unavailable for performance: charter parties, for example, were held to be frustrated where the ship was requisitioned. ${ }^{54}$ In 1918, it was held that the balance of a contract could be frustrated when, at the time of the requisition, a one-year charter still had six months to run: it was unlikely that the ship would be released in time to render any services under the charter. ${ }^{55}$ In some cases, where long delays in performance resulted from wartime restrictions, it was held that performance need not be resumed in the totally altered conditions which prevailed when those

48. Leiston Gas Co. v. Leiston-Cum-Sizewell Urban DC (1916) 2 K.B. 428. See Trotter, Contract (1940), at 131; Treitel, Contract (2003), at 886; Meijers, Verandering (1918), at 102.

49. Nordman v. Rayner \& Sturgess (1916) 33 T.L.R. 87. See Treitel, Contract (2003), at 875

50. Tamplin SS Co. Ltd. v. Anglo-Mexican Petroleum Co. (1916), 2 A.C. 397.

51. Tamplin SS Co. Ltd. v. Anglo-Mexican Petroleum Co. (1916), 2 A.C. 397, at 403-4. Critical McElroy, Impossibility (1941), at 155-65. See also Trotter, Contract (1940), at 120 and 124-26; Gottschalk, Impossibility (1945), at 30-32; Treitel, Contract (2003), at 874; Meijers, Verandering (1918), at 102.

52. McElroy, Impossibility (1941), at 159

53. Taylor v. Caldwell (1863) 3 B. \& S. 826

54. E.g. Anglo-American Trading Co. v. Emlyn Jones \& Williams (1917) 2 K.B. 78; Heilgers \& Co. v. Cambrian Steam Navigation Co. (1917) 34 T.L.R. 720. Trotter, Contract (1940), at 120; Treitel, Contract (2003), at 872-74.

55. E.g. Countess of Warwick SS Co. v. Le Nickel SA (1918) 1 K.B. 372 . See Treitel, Contract (2003), at 874. restrictions were removed. ${ }^{56}$ In Metropolitan Water Board v. Dick Kerr E Co. of 1918, Lord Dunedin laid down a test as to whether a contract should be dissolved or merely suspended: 'An interruption may be so long as to destroy the identity of the work or service, when resumed, with the work or service when interrupted. ${ }^{57}$ This test contained no reference to an implied condition because performance was prevented by supervening legislation. ${ }^{58}$ Courts generally appeared to base the discharge of contracts on the - more objective - frustration of the adventure, and less so on a - subjective - implied condition. ${ }^{59}$ Moreover, in all of these cases commercial impracticability alone was therefore insufficient ground to discharge a contract. ${ }^{60}$

It can be clearly seen that in many cases contracts were held not to be frustrated at all: in 1918, for example, a seller who expected to get supplies of birch timber from Finland - the supply of which had become impossible after the outbreak of war in 1914 - was held to the contract, as only he had intended to use Finland as the sole source of supply. ${ }^{61}$ Also the rise of prices caused by the outbreak of the war did not discharge a contract. ${ }^{62}$

The case law regarding the discharge of contracts by supervening impossibility appeared to be not entirely consistent, not in the least as to why exactly a contract was discharged from a legal point of view, namely, on the basis of an implied condition, frustration of the adventure, or simply for failure of consideration. ${ }^{63}$ However, apart from doctrinal inconsistencies attributable to a developing doctrine of frustration, the increasing number of cases in which contracts were held to be discharged by supervening impossibility - particularly in the years 1917 and 1918 - seems to result from the changing nature of war. The war had become one of attrition for which the entire economy had to be mobilised, for instance by, at the beginning of 1917, placing the whole merchant marine under the authority of a Shipping Controller. ${ }^{64}$

\subsection{France}

Unlike the English judiciary, in the area of private law the French courts never extended impossibility of per-
56. Metropolitan Water Board v. Dick Kerr \& Co. (1918) A.C. 119

57. Metropolitan Water Board v. Dick Kerr \& Co. (1918) A.C. 119, at 128.

58. Metropolitan Water Board v. Dick Kerr \& Co. (1918) A.C. 119, at 130 See McElroy, Impossibility (1941), at 166-67; Gottschalk, Impossibility (1945), at 32-33. See also Trotter, Contract (1940), at 132; Treitel, Contract (2003), at 873, 882; Treitel, Frustration (1994), at 217

59. See McElroy, Impossibility (1941), at 163

60. See, for an overview of war-time cases, Trotter, Contract (1940), at 116. See also Gottschalk, Impossibility (1945), at 34; Treitel, Contract (2003), at 882

61. Blackburn Bobbin Co. Ltd. v. TW Allen Ltd. (1918) 2 K.B. 467. See Trotter, Contract (1940), at 134-35; Treitel, Contract (2003), at 876; Meijers, Verandering (1918), at 101-2.

62. E.g. Tennants (Lancashire) Ltd. v. Wilson \& Co. Ltd. (1917) A.C. 495; Bolckow Vaughan \& Co. v. Compañia Minera de Sierra Minera (1916) 33 T.L.R. 111 (C.A.); Greenway Bros. Ltd. v. Jones \& Co. (1916) 32 T.L.R. 184. See Trotter, Contract (1940), at 116; Mann, Legal Aspect (1982), at 111; Meijers, Verandering (1918), at 103.

63. See, in detail, McNair, War (1966), at 166-77; McElroy, Impossibility (1941), at 150-69.

64. See Broadberry, The United Kingdom (2005), at 214 
formance to include frustration of purpose or economic impracticability. ${ }^{65}$ Holding to their previous views that impossibility of performance must be absolute, ${ }^{66}$ courts ruled that the outbreak of the war and the subsequent increase in the cost or difficulty of performance could not constitute force majeure: e.g. in 1915, a shop had to pay damages under an employment contract to a seamstress, even if no work was available; ${ }^{67}$ and in 1918, a lease was not terminated because an apartment had survived a bombardment, here of the city of Nancy, France. ${ }^{68}$ To alleviate the hardships caused by inflation, chiefly the lower courts manipulated the damage reme$\mathrm{dy}$ - as the measure of recovery generally lies outside the control by the Cour de Cassation. Where a change in the value of goods or services could be attributed to a change in the value of money, a buyer was supposed not to have suffered substantial damage. ${ }^{69}$

In contrast to the attitude taken by the Cour de Cassation, the Conseil d'état during the war further developed and used the doctrine of imprévision, a modified version of economic impracticability, to relieve parties from the effects of war. ${ }^{70}$ The doctrine of imprévision entitled courts to terminate or revise contracts whenever performance became extremely burdensome, though not objectively impossible to one of the parties, due to a substantial and unforeseen change in economic circumstances. ${ }^{71}$ The doctrine was limited to government contractors and was mainly used to alter the rate schedules of public utility companies engaged in the distribution of electricity and gas by ordering payment of an indemnity as compensation for increased costs of production. $^{72}$ In the leading case, Gas de Bordeaux of 1916, the Conseil d'état held that price revision was appropriate because the increase in the cost of performance

'certainly exceeds the outer limits of the increases that could have been contemplated by the parties when the contract of concession was concluded; as a

65. See e.g. Ghestin, Effets (2001), at 307; Mazeaud, Leçons (1998), at 736; Rösler, Hardship (2007), at 500-501; Von Mehren, Civil Law (1977), at 1049; Cooper, Inflation (1936), at 69-70.

66. E.g. Cass. Civ., 6 March 1876, De Galliffet v. Commune de Pélissane, D. 1876.1.193; Cass. Civ., 24 March 1874, Comuset, Heina et comp. v. Way, S. 1874.1.428. See also Von Mehren, Civil Law (1977), at 1050-51; Rösler, Hardship (2007), at 500-501.

67. Cass. Civ., 4 August 1915, Maison Agnes v. Maalderinck, D. 1916.1.22. See Ghestin, Effets (2001), at no. 307; Von Mehren, Civil Law (1977), at 1051-52

68. Cass. req., 3 July 1918, Durlach v. Grandgérard, S. 1918-19.1.160. See Von Mehren, Civil Law (1977), at 1065-66.

69. See, also for more cases, J.P. Dawson and F.E. Cooper, 'The Effect of Inflation on Private Contracts: United States, 1861-1879', 33 Mich. L. Rev. 852, at 890 (1935); Cooper, Inflation (1936), at 75

70. See Fabre-Magan, Contrat (2010), at 480; Ghestin, Effets (2001), at 315; Cooper, Inflation (1936), at 76, 81; Von Mehren, Civil Law (1977), at 549.

71. The legal basis of this doctrine was subject to scholarly debate, see Cooper, Inflation (1936), at 84-87.

72. Ghestin, Effets (2001), at 315; Cooper, Inflation (1936), at 77-78. result ... the contractual equilibrium is completely destroyed. ${ }^{73}$

Here, the increase in the price of coal, needed to make gas, was more than $400 \% .{ }^{74}$ In the interest of maintaining uninterrupted services to the public, the court refused to grant rescission, and, in the absence of agreement by the parties, the general aim was to divide the loss between the two parties. ${ }^{75}$ Relief was initially restricted to long-term contracts formed in pre-war days, but was later extended to short-term contracts formed during the time of war. ${ }^{76}$ Despite its various limitations, ${ }^{77}$ the doctrine proved to be a useful tool in mitigating the effects of inflation in the administrative area during the war. ${ }^{78}$ Probably unsurprisingly, the doctrine of imprévision was of administrative jurisprudence: the Conseil d'état had jurisdiction over all contracts for public service, and it was essential that the fundamental public services be continued. ${ }^{79}$ In case of private contracts, little public harm would result from non-performance, and moreover relief to oppressed obligors sued for breach of contract could be afforded indirectly by trial judges fixing damages. ${ }^{80}$

The French legislature also took an active role during the war (and also post-war) inflation: at least nine statutes were passed trying to ameliorate the position of contractual parties severely affected by inflation, ${ }^{81}$ the most famous of which is the Loi Faillot of 21 January 1918, which essentially integrated the doctrine of commercial impracticability into positive law. This statute permitted termination of certain types of commercial contracts concluded prior to 1 August 1914, calling for successive performances - although, e.g. contracts of loan or lease contracts were excepted - if performance had become unforeseeably onerous to one of the parties. If the parties could not agree to a price revision, the

73. C.E., 30 March 1916, Compagnie Générale d'Eclairage de Bordeaux v. Ville de Bordeaux, D. 1916.3.25, S. 1916.3.17. See Fabre-Magan, Contrat (2010), at 480-81; Ghestin, Effets (2001), at 315; Von Mehren, Civil Law (1977), at 545-47

74. Cooper, Inflation (1936), at 73-74

75. Ghestin, Effets (2001), at no. 315; Cooper, Inflation (1936), at 75-77; Von Mehren, Civil Law (1977), at 548-49.

76. Cooper, Inflation (1936), at 77-79; Von Mehren, Civil Law (1977), at 549.

77. Ghestin, Effets (2001), at 315; Cooper, Inflation (1936), at 78-81; Von Mehren, Civil Law (1977), at 550-51; Mann, Legal Aspect (1982), at 102-3.

78. E.g. C.E. 21 July 1917, Compagnie générale des automobiles postales, Rec. Lebon, 586; C.E., 8 February 1918, Gaz de Poissy, Rec. Lebon, 122. See Ghestin, Effets (2001), at 315. Although the economic disruption after the war was more serious than during the war, particularly between 1919 and 1927, only in a few cases relief was given in this period, probably because most of the electric light companies had achieved a re-making of rates during the war that could carry them through the rest of the inflation era, see Cooper, Inflation (1936), at 75.

79. See Mazeaud, Leçons (1998), at 735; Cooper, Inflation (1936), at 75. Less convinced, Fabre-Magan, Contrat (2010), at 481.

80. See directly above and again Cooper, Inflation (1936), at 75.

81. See, in detail, Cooper, Inflation (1936), at 87-90; Ghestin, Effets (2001), at 300-304; Von Mehren, Civil Law (1977), at 1061-62; Mann, Legal Aspect (1982), at 103; Renner, Inflation (1999), at 15-16. 
statute authorised courts to suspend or resolve the contract with or without award of damages. ${ }^{82}$

\subsection{German Empire}

After the outbreak of war, German courts initially showed great adherence to the literal words of the Bürgerliches Gesetzbuch - probably also motivated by the illusion of a brief war and the desire to continue 'business as usual' - and were unwilling to grant relief to many contracts affected by wartime conditions: ${ }^{83}$ a lessee had to pay pre-war rent for a circus building in Berlin - good faith and commercial morals did not justify in any way whatsoever the shifting to the lessor the loss that the war had caused to the lessee ${ }^{84}$ a magazine could not discharge an editor without notice - the newspaper had not shown that it had to cease publication; $; 5$ a seller had to deliver tin, even if the prices had risen with more than $200 \%$ since the conclusion of the contract - a subjective inability does not free the debtor from an obligation involving a type (Gattungsschuld) so long as performance of this type is possible; ${ }^{86}$ the rent of a beer hall was not reduced, despite the government's order to reduce the total beer production by a third. ${ }^{87}$

Gradually, however, as the war progressed, the courts started to be somewhat more flexible with respect to impossibility of performance, and in certain cases rescission was granted, for instance where a government ban on dancing prevented the lessee to use a dance hall from being used as the contract contemplated. ${ }^{88}$ Also when performance had become temporarily, but for an indefinite period of time, impossible, the Reichsgericht would grant rescission. ${ }^{89}$

82. See Mazeaud, Leçons (1998), at 737; Ghestin, Effets (2001), at 301; Cooper, Inflation (1936), at 87-88; Von Mehren, Civil Law (1977), at 1061-62; Renner, Inflation (1999), at 15.

83. Fundamental on the legal preconditions and consequences of the German hyperinflation from 1914 to 1948, J. Thiessen, 'German Hyperinflation of the 1920s - a Study on Cases', in W. Ernst and D. Fox (eds.), Money in the Western Legal Tradition (forthcoming). See, also on the effects of the war economy on German contract law in general, Dörner, Erster Weltkrieg (1986), at 385, 398-99; S-R. Eiffler, 'Die "Feuertaufe" des BGB: Das Vertragsrecht des Bürgerlichen Gesetzbuchs und das Kriegswirtschaftsrecht des 1. Weltkriegs', 20 Zeitschrift für Neuere Rechtsgeschichte 238-55 (1998); in more detail on the following decisions, Dawson, Effects of Inflation (1934), at 178-81; Beale, Contract (2010), at 1138.

84. Reichsgericht, Third Civil Senate, 4 May 1915 (S. v. B.), 86 ERGZ 397.

85. Reichsgericht, Third Civil Senate, 30 November 1915 (B. v. T.), 87 ERGZ 349.

86. Reichsgericht, Second Civil Senate, 21 March 1916 (C. v. M.), 88 ERGZ 172.

87. Reichsgericht, Third Civil Senate, 3 July 1917 (H. v. Norddeutsche Immobilien-Akt.-Ges.), 90 ERGZ 374.

88. Reichsgericht, Third Civil Senate, 9 November 1915 (P. v. G.), 87 ERGZ 277.

89. E.g. Reichsgericht, 4 January 1916, J.W. 16, 487; Reichsgericht, Second Civil Senate, 4 February 1916, 88 ERGZ 71; Reichsgericht, 23 May 1916, J.W. 16, 1017; Reichsgericht, Second Civil Senate, 27 March 1917, 90 ERGZ 102; Reichsgericht, 6 July 1917, J.W. 18, 33; Reichsgericht, 15 October 1918, 94 ERGZ 45. See Dörner, Erster Weltkrieg (1986), at 399-400; Eiffler, BGB im 1. Weltkrieg (1998), at 252-53; Meijers, Verandering (1918), at 95; Beale, Contract (2010), at 1138; and, for a more detailed overview of the contemporary case law, Dawson, Effects of Inflation (1934), at 181-82.
However, these cases seemed to remain exceptions to the principle that rescission was basically only granted when performance was literally impossible. ${ }^{90}$

\subsection{The Netherlands}

Already before the war, courts had sometimes assimilated the practically impossible with the absolutely impossible, ${ }^{91}$ and this became generally accepted during the war. ${ }^{92}$ However, although the courts adopted the notion of subjective impossibility - or rather commercial impracticability - developed before the war, in hardly any cases force majeure was accepted. ${ }^{93}$ The judiciary simply stressed that the event making performance impossible had to be unforeseen, and this turned out to hardly ever be the case. ${ }^{94}$ Just as the courts in England, France, and the German Empire, Dutch courts during the war appeared to be reluctant to rescind or interfere with contracts because of an increase in prices. ${ }^{95}$ Courts were neither willing to grant relief on the basis of the

90. See Eiffler, BGB im 1. Weltkrieg (1998), at 249-52.

91. E.g. Hof Noord-Brabant, 6 April 1875, W. 3879. See Oosterhuis, Specific Performance (2011), at 376-77.

92. E.g. Rb. Haarlem, 1 June 1915, N.J. 15, 698; Rb. Rotterdam, 30 June 1915, N.J. 15, 855, W. 9800, confirmed Hof Den Haag, 19 November 1915, W. 9905 (force majeure); Rb. Amsterdam, 29 October 1915, N.J. 15, 1186 and 1188; Rb. Rotterdam, 17 December 1915, N.J. 16, 434; Rb. Den Bosch, 26 March 1915, N.J. 16, 439 (no force majeure); Rb. Utrecht, 12 January 1916, N.J. 16, 1050; Hof Amsterdam, 6 October 1916, N.J. 17, 275; Hof Arnhem, 27 March 1917, N.J. 17, 881 (no force majeure); Rb. Amsterdam, 28 April 1916, W. 10071 (no force majeure); Rb. Amsterdam, 14 April 1916, W. 10087 (no force majeure). Exceptionally, Hof Den Haag, 8 December 1916, W. 10129 (price increase of 20 to $25 \%$ cent constitutes force majeure). See Meijers, Verandering (1918), at 135

93. Exceptionally, Hof Den Haag, 8 December 1916, W. 10129 (price increase of 20 to $25 \%$ constitutes force majeure). See Fruin, Verandering (1918), at 72; Meijers, Verandering (1918), at 135.

94. No force majeure because either (i) the event should be unforeseen (Rb. Den Haag, 20 April 1916, W.P.N.R. 2423; Rb. 7 May 1917, N.J. 17, 809; Rb. Amsterdam, 23 November 1917, N.J. 18, 100; Rb. Utrecht, 14 March 1917, N.J. 18, 97); or (ii) the debtor should have foreseen the difficulties (Rb. Utrecht, 18 April 1918, N.J. 17, 1059; Rb. Zwolle, 19 December 1917, N.J. 18, 174); or (iii) the debtor implicitly took the risk (Rb. Rotterdam, 29 June 1915 W. 9854; Rb. Rotterdam 16 December 1915, N.J. 16, 432; Rb. Amsterdam, 25 June 1917, N.J. 17, 876; Rb. Haarlem, 6 November 1917, N.J. 18, 176) or (iv) the debtor has to bear the risk according to the law (Rb. Rotterdam, 5 October 1916, N.J. 17, 883). See Wery, Overmacht (1919), at 95-96. Levenbach, Kontraktsband (1923), at 107, lists another twelve war-time cases in which no force majeure was accepted because the event was not considered to be unforeseen. See also Levenbach, Kontraktsband (1923), at 113-14.

95. E.g. Rb. Amsterdam, 4 December 1914, W. v. N. en P. 2351; Rb. Den Bosch, 26 March 1915, N.J. 16, 439; Hof Amsterdam, 2 March 1917, W. 10140; Hof Arnhem, 27 March 1917, N.J. 17, 881; Rb. Amsterdam, 23 November 1917, N.J. 18, 100; Rb. Dordrecht, 5 December 1917, N.J. 18, 177. Exceptionally otherwise, Hof Den Haag, 8 December 1916, W. 10129 (price increase of 20 to $25 \%$ constitutes force majeure). See Levenbach, Kontraktsband (1923), at 203; Th.A. Fruin, 'Behoort verandering in de feitelijke omstandigheden, waaronder een overeenkomst is gesloten, invloed te hebben op haar voortbestaan? Zoo ja, welke wettelijke regeling is te dien aanzien wenschelijk?', in Handelingen der Nederlandsche Juristen-Vereeniging I.1 (1918) 1, at 72; Meijers, Verandering (1918), at 176. Critical about possible force majeure because of an increase in prices, W.L.P.A. Molengraaff, De gevolgen van den oorlog op handelsovereenkomsten, in het bijzonder op leveringscontracten (1915), at 23-25. 
good faith principle in, e.g. Article 1374(3) of the Burgerlijk Wetboek. ${ }^{96}$

\section{Post-1918: Inflation and 'Open' versus 'Closed' Systems}

The recovery from the war varied in Britain, France, Germany, and the Netherlands, although most governments tried to return to the pre-war gold standard due to widespread belief that such was necessary if the growth and prosperity of the pre-1914 era were to be reestablished. ${ }^{97}$

The older British industrial centres lagged behind international competitors. Therefore, prices were to be held low to support British exports, which led to severe deflationary policies in 1919 and 1929. However, the British government had returned to the gold standard and, for instance, in 1924 the pound was overvalued, severely hampering exports. Therefore, Britain's recovery only came about slowly, around $1937 .{ }^{98}$

The old industries in France also suffered from international competition. However, new industries soon grew substantially. France did not return to the gold standard, and French exports benefitted from the decline in value of the franc. Investment was made easier through inflation. However, with the depression, French exports dropped $60 \%$ between 1929 and 1935, also due to the overvalued franc, as other countries abandoned gold as well. ${ }^{99}$

Though defeated and burdened with reparations payments, Germany boomed through 1922 while other industrial economies faltered. Germany had suffered only the indirect damage of neglected maintenance and delayed replacement during the war. The government allowed the exchange rate to slip and made credit available through the Reichsbank, especially to large firms. Favoured companies could obtain credit, purchase competitors, repay the loans in a depreciated currency, and repeat the cycle with new loans. This process was well under way before the Ruhr crisis of 1923, when the government started printing money to support striking miners; ultimately this led to the hyperinflation in $1923 .^{100}$

96. The register of the Weekblad van het Regt over the years 1914-1918 shows that contract revision on the basis of Article 1374(3) BW was hardly ever claimed; when it was, it was denied, see e.g. Hof Amsterdam, 7 April 1916, W. 10032. See also Rb. Almelo, 5 January 1916, N.J. 16, 1162. Otherwise Rb. Rotterdam, 20 April 1916, N.J. 16, 1217. See Meijers, Goede trouw (1937), at 281; Wery, Overmacht (1919), at 59-64.

97. See C.H. Feinstein, P. Temin \& G. Toniolo, The European Economy between the Wars (1997), at 1.

98. See Tipton, Europe (1987), at 169-72; Damsgaard Hansen, History (2001), at 221-22.

99. See Tipton, Europe (1987), at 172-75.

100. See Tipton, Europe (1987), at 175-77; Damsgaard Hansen, History (2001), at 223-24.
Between 1913 and 1919, the Netherlands had the highest growth rates of Western Europe. It profited from the German boom and the export of food to Britain. In the 1930s, however, the Dutch economy was hit by the depression. Sticking to the gold standard - probably motivated by the interests of an influential financial sector - meant a further loss of competitiveness. In 1936, the guilder was to be devalued by $20 \%{ }^{101}$

It was only because of the inflation after the war that German courts started to explicitly interfere in contracts where performance was not impossible but 'merely' impracticable. This changing attitude therefore strongly reflects the economic conditions of the respective jurisdictions: Germany knew hyperinflation in the 1920s and is now an 'open' system; Britain, France, and the Netherlands did not and are still 'closed' systems - despite a statutory basis in Article 6:258 of the Dutch Burgerlijk Wetboek to modify or set aside contracts in case of frustration.

\subsection{England}

The case law in the first decade after the war was a continuation of the wartime decisions. Rather, the immediate post-war cases are really cases which arose during the war, and it is likely that this influenced the resolution of these cases. Indeed, directly after the war in several more cases discharge was given because the subjectmatter, a person or thing, had become - temporarily unavailable for performance: these contracts often concerned charter parties that were frustrated where the ship was requisitioned by the government. ${ }^{102}$ Also in Bank Line Ltd. v. Arthur Capel E Co. of 1919, it was held by the majority that a coal charter from September to the following September was a substantially different thing from a coal charter from April to the following April, and that by implication the contract was discharged by frustration of the adventure. ${ }^{103}$ In cases where long delays in performance resulted from wartime restrictions, it was held that performance need not be resumed in the totally altered conditions which prevailed when those restrictions were removed after the war. $^{104}$

However, in the course of the Second World War, particularly the implied condition theory was criticised as being dependent on the - subjective - intentions of the parties, thus widening the potential application of the doctrine of frustration. ${ }^{105}$ The Second World War gave rise to few reported cases in which contracts were held

101. See Tipton, Europe (1987), at 181-82; Damsgaard Hansen, History (2001), at 226, 244; De Jong, Dutch Economy (2005), at 144

102. E.g.Bank Line Ltd. v. Arthur Capel \& Co. (1919) A.C. 435; Hirii Mulji v. Cheong Yue SS. Co. (1926) A.C. 497. See Trotter, Contract (1940), at 132; Treitel, Contract (2003), at 872-74; Treitel, Frustration (1994), at 53.

103. Bank Line Ltd. v. Arthur Capel \& Co. (1919) A.C. 435. See McElroy, Impossibility (1941), at 167-69.

104. E.g. Acetylene Co. of GB v. Canada Carbide Co. (1922) 8 LI.L.Rep. 456. See also Treitel, Contract (2003), at 873, 882; Treitel, Frustration (1994), at 217.

105. See e.g. P.H.T. Rogers, The Effect of War on Contract (1940), at 50-51; McElroy, Impossibility (1941), at 159; Gottschalk, Impossibility (1945), at 30-31. See also Treitel, Frustration (1994), at 579-80. 
to be frustrated otherwise than by supervening illegality, i.e. a government prohibition. ${ }^{106}$

In the British Movietonems ${ }^{107}$ case of 1952, the House of Lords rejected the view that a mere uncontemplated turn of events (in that case, the cessation of wartime conditions in which the contract was made) was grounds for frustration. ${ }^{108}$ Lord Simon said:

'The parties to an executory contract are often faced, in the course of carrying it out, with a turn of events which they did not at all anticipate - a wholly abnormal rise or fall in prices, a sudden depreciation of currency, an unexpected obstacle to the execution, or the like. Yet this does not in itself affect the bargain which they have made. ${ }^{109}$

Inflation therefore does not seem to be a ground for discharge. ${ }^{110}$ In the Davis Contractors ${ }^{111}$ case of 1956 , it was confirmed that 'impracticability' was generally not sufficient to frustrate a contract in English law: only a 'fundamental' change of circumstances would bring the doctrine of discharge into play. Moreover, in this case Lord Radcliffe advanced that the doctrine of frustration is explained as occurring by operation of law rather than upon the construction of an implied term. ${ }^{112}$

Since the two aforementioned cases, there seems to be some narrowing in the scope of the doctrine of frustration. ${ }^{113}$ The Suez crisis of 1956, the closing of the Suez Canal again in 1967, the oil crisis in 1973, and the outbreak of hostilities between Iran and Iraq in 1980 all resulted in relatively few cases in which contracts were discharged on the doctrine of frustration. ${ }^{114}$

\subsection{France}

During the war, the Cour de Cassation never extended impossibility of performance to include frustration of purpose or economic impracticability - unlike the English or German judiciaries. Also after the war, when inflation started to rise, ${ }^{115}$ the Cour de Cassation refused to give judicial relief on grounds of monetary depreciation. Although the language and the spirit of the Code civil were indeed generally unfavourable towards such judicial relief, ${ }^{116}$ there were a number of clauses which

106. See Treitel, Contract (2003), at 868 and 887; Treitel, Frustration (1994), at 50.

107. British Movietonews Ltd. v. London and District Cinemas (1952) A.C. 166.

108. See Treitel, Contract (2003), at 867; Mann, Legal Aspect (1982), at 111.

109. British Movietonews Ltd. v. London and District Cinemas (1952) A.C. 166, at 185.

110. Treitel, Frustration (1994), at 275-76. Otherwise Mann, Legal Aspect, at 111

111. Davis Contractors Ltd. v. Fareham Urban DC (1956) A.C. 696.

112. See Treitel, Frustration (1994), at 9, 49, 578-84; Treitel, Contract (2003), at 881; Mann, Legal Aspect (1982), at 111; Beale, Contract (2010), at 1115-18.

113. Many factors account for this trend: see Treitel, Contract (2003), at 868; Treitel, Frustration (1994), at 49-51.

114. See Treitel, Contract (2003), at 868; Treitel, Frustration (1994), at 50.

115. See Von Mehren, Civil Law (1977), at 1054 (with reference to E. Dulles, The French Franc 1914-1928 (1929), at 511)

116. E.g. Articles 1652 and 1895 Code civil. could serve as a basis for relief, most prominently Article 1134 . However, standing by its decision in the Canal de Craponne case that impossibility of performance must be absolute, ${ }^{117}$ the Cour de Cassation ruled that the rise in prices after the war did not excuse the parties from performance: in the case Bacou v. Saint-Pé of 1921, the tenant had - at the end of the lease - the option to either return the leased livestock or its value, which had been determined in advance, at the conclusion of the lease on 4 December 1910. Here, the owner argued in vain that he was entitled to at least part of the increase in market value of the livestock: ${ }^{118}$ in 1920 , retail prices had increased by more than $300 \%$ since the beginning of the war in 1914. ${ }^{119}$

Basically the only doctrine of French private law employed by the Cour de Cassation to relieve creditors of the effects of inflation was the doctrine of lésion. According to the doctrine of lésion, a seller of land who receives less than five-twelfths of the land's true value, as determined by a commission of three experts, is entitled to rescission unless the buyer offers to increase the consideration to nine-tenths of the true value. ${ }^{120}$ After the war, the franc underwent a period of constant weakening, interrupted by periods of rapid depreciation, viz. between 1918 and early 1921, ${ }^{121}$ and between the end of 1923 and July 1926, when Poincaré stabilised the currency. ${ }^{122}$ When the franc started to depreciate rapidly, the Cour de Cassation, departing from its previous position, held that with respect to fixed-price options for the sale of land, the relevant date was not that of agreement on but of exercise of the option. ${ }^{123}$

\subsection{German Republic}

Unsurprisingly, by the beginning of 1919 the Reichsgericht still held that

117. E.g. Cass. Civ., 6 March 1876, De Galliffet v. Commune de Pélissane, D. 1876.1.193; Cass. Civ., 24 March 1874, Comuset, Heina et comp. v. Way, S. 1874.1.428. See also Von Mehren, Civil Law (1977), at 1050-51; Rösler, Hardship (2007), at 500-501.

118. Cass. Civ., 6 June 1921, Bacou v. Saint-Pé, D. 1921.1.73, S. 1921.1.193. See Ghestin, Effets (2001), at 307; Beale, Contract (2010), at 1032-34; Von Mehren, Civil Law (1977), at 1052-53. See also e.g. Cass. civ., 15 November 1934, Société Anon. v. Cie. des Mines de Graissessac, Gaz. Pal. 1934.1.68. See Von Mehren, Civil Law (1977), at 1056.

119. See Von Mehren, Civil Law (1977), at 1054 (with reference to E. Dulles, The French Franc 1914-1928 (1929), at 511)

120. Articles 1674-84 Code civil. See Fabre-Magan, Contrat (2010), at 411-14; Mazeaud, Leçons (1998), at 209-24; J. Gordley and A.T. von Mehren, An Introduction to the Comparative Study of Private Law (2006), at 464; Cooper, Inflation (1936), at 68.

121. Wholesale prices increased from 360 in December 1918 to 444 in December 1920, see Von Mehren, Civil Law (1977), at 1053-54 (reference to Dulles, Franc (1929), at 510).

122. Wholesale prices increased from 429 in November 1923 to 854 in July 1926, see Von Mehren, Civil Law (1977), at 1053-54 (reference to Dulles, Franc (1929), at 510).

123. E.g. Cass. req., 1 August 1924, De Scorailles v. Le Fer de Bonbon, S. 1926.1.54 (concerning an option given in 1912 and exercised in April 1922); CA Paris, 12 November 1928, De Coubertin v. D'Avaray, D. 1929.42 (concerning an option given in 1905 and exercised in 1925). See Ghestin, Effets (2001), at 334; Von Mehren, Civil Law (1977), at 1063-64; Renner, Inflation (1999), at 14-15. 
'A mere rise in price cannot release the seller, even if it results in considerable loss to him, from his contractual obligation. There would be no standard for determining what degree of loss was required before this liberation would be permitted. This would lead to an intolerable degree of legal uncertainty. ${ }^{124}$

But prices during the years 1918-19 went up much more rapidly than before, and in two decisions of December 1919 and July 1920 the Reichsgericht was willing to recognise that although a rise in prices is by itself insufficient, if dislocation of industry and trade were to make performance 'essentially different' than that contracted for, ${ }^{125}$ or lead to the economic ruin of a party to a contract, ${ }^{126}$ rescission should be granted. ${ }^{127}$ In September 1920, the Reichsgericht then extended the concept of impossibility to include economic impossibility and turned to good faith and the general theory of clausula rebus sic stantibus as the legal resources available to deal with contracts affected by inflation. ${ }^{128}$ For the first time, the Reichsgericht ordered a revision of the price, the loss to be fairly apportioned between the parties. ${ }^{129}$ However, the Reichsgericht restricted the possibility of rescission or price revision to extreme circumstances, depending on the factual circumstances of each case, and emphasised whether enforcement of the contract would lead to the economic ruin of the party seeking relief. ${ }^{130}$ Moreover, contractors whose continuing performance would end up in positive loss ${ }^{131}$ were treated differently from those whose continuing performance would lead to a lost gain: ${ }^{132}$ the courts were more willing to grant relief to the former than to the latter.

Nevertheless, by the end of 1921, the mark started to depreciate rapidly and the courts, recognising that changes in prices were mainly attributable to changes in the value of money, were willing to grant relief in wholesale transactions. ${ }^{133}$ In a decision of November 1921, the Reichsgericht gave up the requirement of economic ruin as basis for relief and developed new theories of fair equivalence of performance ${ }^{134}$ and 'changed conditions ${ }^{\prime 135}$ under the provision of good faith. The remedy granted to the creditor under such theories was

124. Reichsgericht, Second Civil Senate, 25 February 1919 (B. v. Berliner Maschinenbau-Aktiengesellschaft), 95 ERGZ 41.

125. Dawson, Effects of inflation (1934), at 184.

126. Reichsgericht, Third Civil Senate, 8 July 1920 (B. v. F.), 99 ERGZ 258.

127. Fundamental and in great detail on the German hyperinflation cases in the 1920s, Thiessen, German Hyperinflation (forthcoming).

128. Reichsgericht, Third Civil Senate, 21 September 1920 (Sp. Co. v. F. Co.), 100 ERGZ 129. See Dörner, Erster Weltkrieg (1986), at 400; Wieacker, Das Sozialmodell (1974), 25.

129. Beale, Contract (2010), at 1138.

130. Reichsgericht, Fifth Civil Senate, 16 April 1921 (P. \& Co. v. M.), 102 ERGZ 98.

131. Reichsgericht, Third Civil Senate, 21 September 1920 (Sp. Co. v. F. Co.), 100 ERGZ 129. See Dawson, Effects of Inflation (1934), at 184.

132. Reichsgericht, Fifth Civil Senate, 16 April 1921 (P. \& Co. v. M.), 102 ERGZ 98. See Dawson, Effects of Inflation (1934), at 187-88.

133. Reichsgericht, Second Civil Senate, 29 November 1921 (Marseiwerke v. H.), 103 ERGZ 177.

134. Reichsgericht, Second Civil Senate, 29 November 1921 (Marseiwerke v. H.), 103 ERGZ 177

135. Dawson, Effects of Inflation (1934), at 193. rescission, unless the debtor was willing to pay a reasonable increase in the contract price. ${ }^{136}$ The rapid depreciation soon culminated in two decisions of February 1922 and June 1922, in which the Reichsgericht recognised judicial revision and considered that revision should be preferred over rescission. ${ }^{137}$ Moreover, these judgements were the first to openly acknowledge Oertmann's theory of the Wegfall der Geschäftsgrundlage (disappearance of the contractual basis) as a basis for that revision. ${ }^{138}$ Finally, the latter judgement implicitly recognised for the first time that the face value of the mark might not be its value for legal purposes. ${ }^{139}$ Still the Reichsgericht emphasised the limited scope of these decisions to the particular circumstances of the case. The primary focus of judicial interference up to this point had been bilateral contracts for sale or performance of services. ${ }^{140}$ Outside the field of commercial contracts, only certain contracts having social impact, such as alimony payments or payment for the purpose of support and maintenance, were granted relief. ${ }^{141}$

On 28 November 1923, however, when the dollar parity of the mark was quoted at 4.2 trillion, the Reichsgericht gave the most famous decision, which stated that under the new circumstances of inflation, the legal tender legislation contradicted the provision of good faith of the Bürgerliches Gesetzbuch $\$ 242$ and the latter must be given precedence over the former. ${ }^{142}$ For the first time, the Reichsgericht ordered revalorisation of simple money debts, ${ }^{143}$ the rate to be fixed by the court failing the parties' agreement on a fair price. The Reichsgericht suggested that in determining the amount of revalorisation, a case-by-case fair determination of the interests of both parties was required. ${ }^{144}$ From this decision, a new era of - enormously difficult - judicial revalorisation had started. $^{145}$

The major reform of the Bürgerliches Gesetzbuch in 2002 eventually supplied a statutory basis for the doctrine of the disappearance of the contractual basis (Wegfall der Geschäftsgrundlage) in $\S 313$. The provision was designed to codify the case law as it had developed since the 1920 s. ${ }^{146}$

136. Dawson, Effects of Inflation (1934), at 193-94.

137. Reichsgericht, 3 February 1922, 103 ERGZ 328; Reichsgericht, Third Civil Senate, 27 June 1922 (K. v. W.), 104 ERGZ 394. See Beale, Contract (2010), at 1139-41.

138. P. Oertmann, Die Geschäftsgrundlage. Ein neuer Rechtsbegriff (1921). See Markesinis, Contract (2006), at 322; Beale, Contract (2010), at 1141. The resemblance with the English doctrine of frustration as explained in Metropolitan Water Board v. Dick Kerr \& Co. (1918) A.C. 119 , is striking. See above 3.3 .

139. Renner, Inflation (1999), at 10

140. Renner, Inflation (1999), at 11

141. Dawson, Effects of Inflation (1934), at 198-99.

142. Reichsgericht, Fifth Civil Senate, 28 November 1923 (St. v. R.), 107 ERGZ 78.

143. Renner, Inflation (1999), at 11.

144. Renner, Inflation (1999), at 12

145. Renner, Inflation (1999), at 11.

146. See Markesinis, Contract (2006), at 324, 327-30; Beale, Contract (2010), at 1141-1148 


\subsection{The Netherlands}

After the war, force majeure was accepted in hardly any cases as reason to discharge a contract. The judiciary again stressed that the event making performance impossible had to be unforeseen, and this turned out to hardly ever be the case. ${ }^{147}$ During the war, the assimilation of the practically impossible with the absolutely impossible had become generally accepted. ${ }^{148}$ However, just as the courts in England, France, and the German Empire, Dutch courts after the war appeared to be reluctant to rescind or interfere with contracts because of an increase in prices. ${ }^{149}$ Although the Hoge Raad in 1923 had decided that whether or not a contract had been performed in good faith, the subjective intention of the parties was not decisive but the objective criteria of reasonableness and equity, ${ }^{150}$ this remained an exception. In the following decade, the Hoge Raad consistently refused to grant relief on the basis of the principle of good faith in e.g. Article 1374(3) of the Burgerlijk Wetboek. ${ }^{151}$

In 1977, the Hoge Raad - probably for the first time held that under unforeseen and very serious circumstances, according to criteria of reasonableness and equity, a debtor - here a fraudulent physician - could not expect the contract to be maintained in its unlimited form. ${ }^{152}$ The new Dutch Civil code of 1992, in line with this case law and the ideas of Meijers, provided that the court could modify the effects of a contract or set it aside in whole or in part on the basis of unforeseen circumstances which are of such a nature that the co-contracting party, according to criteria of reasonableness and equity, may not expect the contract to be maintained in an unmodified form (Article 6:258 of the Burgerlijk Wetboek (1992)). ${ }^{153}$ However, despite this statutory basis, Dutch courts hardly ever modify a contract but seem to adhere to a 'closed' system in judicial practice. ${ }^{154}$

147. Levenbach, Kontraktsband (1923), at 107, lists for the years 1919 to 1921 fourteen cases: in just one of these the contract was discharged by force majeure because the event was considered to be unforeseen.

148. See above 3.4. and also Meijers, Verandering (1918), at 135.

149. E.g. Hof Amsterdam, 3 March 1919, W. 10488; Rb. Den Haag, 15 April 1919, W. 10472 confirmed Hof Den Haag, 4 October 1920, W. 10780. See Levenbach, Kontraktsband (1923), at 203.

150. HR, 9 February 1923, W. 11039. See Meijers, Goedetrouw (1937), at 281; Wery, Overmacht (1919), at 59-64.

151. Meijers, Goede trouw (1937), at 281, lists fifteen cases for the period 1925 to 1936 in which the Hoge Raad held that a court may never on the basis of good faith revise or discharge what has been agreed upon between the parties.

152. HR, 16 December 1976, NJ 76, 136 (Ziekenfonds). Probably this wording was influenced by the $1961 \mathrm{draft}$ for a new Dutch Civil code: see on this draft and also about Meijers' influence on it, K. Bezemer, 'Meijers on imprévision in 1918, in 1937, in 1950, and today', in A.G. Castermans et al. (eds.), Foreseen and unforeseen circumstances (2012) 3, at 11-13. See also HR, 27 April 1984, NJ 84, 679 (Nationale Volksbank/ Sipke Helder). See Bezemer, Meijers (2012), at 13.

153. See Bezemer, Meijers (2012), at 11-3.

154. See Hondius, Unexpected circumstances (2011), at 643. See also HR, 20 February 1998, NJ 1998, 493 (Briljant Schreuders/ABP).

\section{Conclusion}

Before coming to any conclusions, a brief summary of the above observations will be made.

Firstly, before the war the English, French, German, and Dutch legal systems had rather uncompromising attitudes towards unforeseen circumstances. Discharge would be granted only in the case of absolute impossibility, although exceptionally in the English, German, and Dutch jurisdictions a kind of subjective impossibility was considered enough. This strict approach runs parallel with the stable economic circumstances before the war, the then prevailing liberal, individualist economic theories, and legal doctrines concerning the sanctity of contract and the right to specific performance, expressed e.g. in the rule pacta sunt servanda.

Secondly, during the war, the courts - perhaps surprisingly - more or less continued their pre-war approach of only allowing contract rescission in cases of absolute impossibility. The English and German courts somewhat relaxed this strict approach, for instance in the sense that they held a contract discharged if performance after a period of temporal impossibility would amount to something completely different than that of the contract conclusion. The French judiciary was divided in a strict sense between the Cour de cassation, which adhered to an absolute impossibility doctrine, and the Conseil d'état, which followed the doctrine of imprévision. The Dutch courts seemed to even restrict the scope of discharge because of supervening impossibility. Although the war caused hardship in the various countries, their economies still functioned: in some cases indeed supervening impossibility occurred, but in many cases it was still very much business as usual. During the war, English, French, German, and Dutch courts thus managed to uphold the sanctity of contract and its underlying adagium pacta sunt servanda - though falteringly and with increasing difficulty towards the end of the war.

Thirdly, only after war, due to their various experiences the legal systems took a different course. In England, France, and the Netherlands, the courts continued their existing approach, or rather even restricted it again, as was the case in England: the sanctity of contract was saved. ${ }^{155}$ In Germany, however, as inflation progressed and the rise in prices was more clearly the result of currency fluctuations rather than of the value of commodities, the courts relaxed their attitude towards the legal consequences of contracts affected by inflation. ${ }^{156}$ The experience gained from the events occurring in Germany led to a gradual development towards an 'open' system, during the various stages of inflation. ${ }^{157}$ Clearly the rate of inflation played the primary role in shaping the courts' attitudes. Direct price revision was ordered for the first time in Germany only in 1920, when prices

\footnotetext{
155. See e.g. Mazeaud, Leçons (1998), at 730.

156. Renner, Inflation (1999), at 11

157. The following discussion relies partly on Renner, Inflation (1999), at 16-17.
} 
were about eight to ten times higher than their pre-war level. Even then, revision was limited through the requirement of economic ruin and was made dependent upon the factual circumstances of each case. Only by the end of 1921, when prices were about 50 times higher than their pre-war level, did courts turn to a more general theory of intervention, though large-scale revision began only at the end of 1923, when the collapse of the currency was complete.

During the war, the English, French, and Dutch experience resembled the German experience, and all managed to maintain the sanctity of contract. It was only after the war that these experiences diverged: although the British, French, German, and Dutch economies all struggled and knew inflation, only Germany experienced hyperinflation and the collapse of its currency. The British, French, and Dutch inflation levels at their peaks never exceeded a tenfold increase in the level of prices. ${ }^{158}$

Since the hyperinflation in the aftermath of the war, Germany had an 'open' system, which provides for either revision or rescission in cases of frustration of contract. England, France, and the Netherlands, did not experience such hyperinflation and remained 'closed': England has, although impossibility is not necessarily absolute, only rescission in case of frustration; the French Cour de cassation adheres to an absolute impossibility doctrine - although the Conseil d'état applies the doctrine of imprévision to government contracts; the Dutch courts hardly ever modify a contract - despite a statutory basis in Article 6:258 of the new Dutch Burgerlijk Wetboek of 1992 to modify or set aside contracts in case of frustration - and thus adhere to a 'closed' system in judicial practice. ${ }^{159}$

The following hypothesis can be formulated on the basis of the above observations: only countries which have experienced economic disaster, such as hyperinflation, might develop an 'open' system; otherwise countries will tend to retain 'closed' systems, which has been the norm since the late nineteenth century: pacta sunt servanda.

Indeed, several other countries with legal systems which have been classified as 'open' in legal practice - such as Austria, Slovenia, and Greece ${ }^{160}$ - experienced hyperinflation, either in the aftermath of the First World War - Austria and Slovenia (as former part of the Habsburg Empire) - or the Second World War - Greece. ${ }^{161}$ Other countries with legal systems which have been classified as 'closed' in legal practice - Belgium, Denmark, Ireland, and Scotland ${ }^{162}$ - did not experience such hyper-

158. See Renner, Inflation (1999), at 25 and Mitchell, Statistics (1978), at 389-91 (Table H1, Wholesale Price Indices).

159. See Hondius, Unexpected circumstances (2011), at 643.

160. See Hondius, Unexpected circumstances (2011), at 643-44.

161. See Renner, Inflation (1999), at 25; Mitchell, Statistics (1978), at 390 (Table H1, Wholesale Price Indices).

162. See Hondius, Unexpected circumstances (2011), at 643-44. inflation in the aftermath of the First or Second World War. ${ }^{163}$

Economic situations do not produce legal forms automatically but only contain the chance that, when a legaltechnical discovery is made, it may also be propagated. ${ }^{164}$ Here, however, the relation between the experience of hyperinflation in the aftermath of the First World War and the development of an 'exceptional' remedy for unexpected circumstances is quite strong. Nevertheless, a shared European experience in this field seems a high price for a shared European remedy for unexpected circumstances.

163. See Mitchell, Statistics (1978), at 390-91 (Table H1, Wholesale Price Indices).

164. See M. Weber, Wirtschaft und Gesellschaft. Die Wirtschaft und die gesellschaftlichen Ordnungen und Mächte. Nachlaß, 3: Recht (MWG I/ 22-3) (2010), 346: 'Ökonomische Situationen gebären neue Rechtsformen nicht einfach automatisch aus sich, sondern enthalten nur eine Chance dafür, daß eine rechtstechnische Erfindung, wenn sie gemacht wird, auch Verbreitung finde.' 